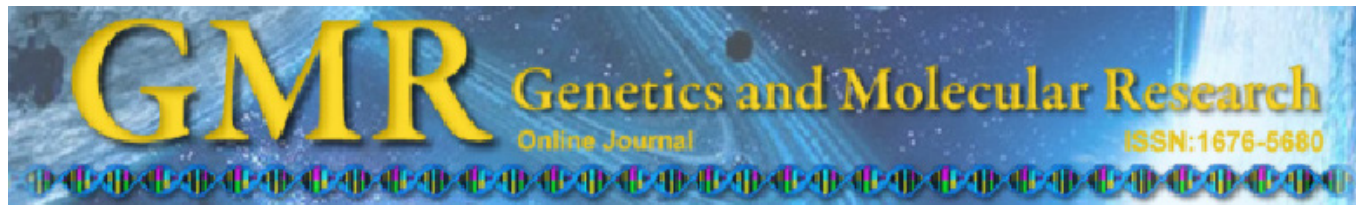

\title{
Structural and functional characterization of the Colletotrichum lindemuthianum nit1 gene, which encodes a nitrate reductase enzyme
}

\author{
G.B. Nogueira, M.V. Queiroz, R.A. Ribeiro and E.F. Araújo \\ Departamento de Microbiologia, \\ Instituto de Biotecnologia Aplicada à Agropecuária, \\ Universidade Federal de Viçosa, Viçosa, MG, Brasil \\ Corresponding author: M.V. Queiroz \\ E-mail: mvqueiro@ufv.br
}

Genet. Mol. Res. 12 (1): 420-433 (2013)

Received May 17, 2012

Accepted July 27, 2012

Published February 8, 2013

DOI http://dx.doi.org/10.4238/2013.February.8.7

\begin{abstract}
Colletotrichum lindemuthianum is the causal agent of plant bean anthracnose, one of the most important diseases affecting the common bean. We investigated the structure and expression of the nit1 gene (nitrate reductase) of $C$. lindemuthianum. The nit1 gene open reading frame contains $2787 \mathrm{bp}$, interrupted by a single 69-bp intron. The predicted protein has 905 amino acids; it shows high identity with the nitrate reductase of $C$. higginsianum (79\%) and C. graminicola (73\%). Expression of nit 1 in C. lindemuthianum was evaluated in mycelia grown on different nitrogen sources under conditions of activation and repression. The gene was expressed after $15 \mathrm{~min}$ of induction with nitrate, reaching maximum expression at $360 \mathrm{~min}$. The transcription was repressed in mycelia grown in media enriched with ammonia, urea or glutamine. Twenty nit $1^{-}$mutants were obtained in a medium treated with chlorate. Ten of these mutants were characterized by DNA hybridization, which identified point mutations, a deletion and an insertion. These rearrangements in the nit 1 gene in the different mutants may have occurred through activity of transposable elements.
\end{abstract}

Key words: Colletotrichum lindemuthianum; Nitrate reductase; Anthracnose; Phaseolus vulgaris 


\section{INTRODUCTION}

Colletotrichum is one of the most important phytopathogenic fungi. The species belongs to the group ascomycetes, which contains several species capable of causing anthracnose on a wide variety of crops and ornamental plants. Many of these species have been used as models for the study of differentiation and plant-pathogen interaction. Colletotrichum lindemuthianum is the causal agent of anthracnose in the common bean (Phaseolus vulgaris L.). The frequent occurrence of moderate temperatures, combined with high humidity, favors disease development and may cause losses of up to $100 \%$ as well as depreciation in the quality of grains. This fungus exhibits a life cycle of 2 phases, a biotrophic and a necrotrophic one, and is therefore classified as hemibiotrophic (Perfect et al., 1999).

C. lindemuthianum has high genetic variability, manifested by the presence of numerous physiological races. This significant genetic variability is one of the most serious obstacles in combating this pathogen because it prevents the long-term use of resistant cultivars (Rodríguez-Guerra et al., 2003; Ansari et al., 2004). Many mechanisms have been proposed to explain the large pathogenic variability and genetic instability that exists in species of Colletotrichum. Among these mechanisms, we can highlight conidial anastomosis, the sexual cycle, the parasexual cycle, and mutations caused by the presence of transposable elements (Casela and Frederiksen, 1994; Ishikawa et al., 2010).

Several strategies have been used to identify active transposable elements in phytopathogenic fungi. One of them employs the principle of spontaneous inactivation of the nit 1 gene, which encodes the nitrate reductase enzyme involved in nitrate assimilation (Daboussi and Capy, 2003; Fávaro et al., 2007). In addition, transformation systems using the nit1 gene can be easily developed (Pereira et al., 2004; Navarrete et al., 2009), and this gene can also be used as a trap to detect transposable elements (Langin et al., 1995). nit1- mutants are obtained by positive selection in media containing chlorate and characterized further in culture media containing different nitrogen sources. Such mutants are widely used in determining vegetative compatibility groups (Oliveira and Costa, 2003) and obtaining recombinants through the parasexual cycle (Castro-Prado et al., 2007).

The last decade has witnessed a revolution in the genomics of the fungal kingdom. Since the sequencing of the first fungus in 1996, the number of available fungal genome sequences has increased by an order of magnitude. Moreover, many of these sequenced species form clusters of related organisms designed to enable comparative studies (Galagan et al., 2005). In 2006, the USDA/National Science Foundation Microbial Genome Sequencing Project was funded by the National Research Initiative to sequence the genome of $C$. graminicola, a major cause of stalk rot disease and one of the most economically important diseases of maize. $C$. graminicola strain M1.001 (also known as M2) is the first member of the Colletotrichum genus to be fully sequenced. The sequence data were generously donated to the public by DuPont in 2008 (Colletotrichum Sequencing Project, Broad Institute of Harvard and MIT [http:// www.broadinstitute.org/]). Another species for which the genome has recently been released is the pathogenic ascomycetes $C$. higginsianum that causes anthracnose in many plants of the Brassicaceae family, including Arabidopsis thaliana. The C. higginsianum genome has been sequenced at the Max Planck Institute for Plant Breeding Research, Cologne, Germany, with funds from the Max Planck Society (Colletotrichum Sequencing Project, Broad Institute of Harvard and MIT [http://www.broadinstitute.org/]). In this study, we report the isolation and structural and functional characterization of the nitl gene in the phytopathogenic fungus $C$. 
lindemuthianum, and provide a comparative analysis with the nit 1 sequences of $C$. graminicola and C. higginsianum.

\section{MATERIAL AND METHODS}

\section{Microorganisms, culture conditions, and DNA isolation}

We used isolated C. lindemuthianum fungus identified as 65-400, 72-801, 73-497, 81, 81-401, and 89. These isolates belong to the collection of the Laboratory Molecular Genetics of Plants, Department of General Biology, Federal University of Viçosa, Brazil. We also used the following strains of Escherichia coli: DH5 $\alpha$ (Promega ${ }^{\circledR}$, Brazil, One Shot ${ }^{\mathbb{}}$ TOP10 (Invitrogen, Brazil), and XLI-Blue MRA (Agilent Technologies ${ }^{\circledR}$, Brazil).

Total DNA of $C$. lindemuthianum was isolated following the protocol established by Specht et al. (1982).

\section{Selection of recombinant phages from the genomic library}

For the isolation of the nitl gene, we used the methodology described by Benton and Davis (1977), i.e., hybridization of DNA to single plaques in situ. Recombinant phages were isolated from the $C$. lindemuthianum genomic library, which was constructed by Soares (2007) using the Lambda EMBL3/BamHI Vector Kit (Agilent Technologies ${ }^{\circledR}$ ). We used the pNIT2.1 plasmid as a probe, courtesy of Thierry Langin (Institut de Biotechnologie des Plantes, Université Paris, France), which contains a genomic insert of part of the nitl gene of $C$. lindemuthianum. Hybridizations were performed at $65^{\circ} \mathrm{C}$, and fragments of labeled DNA were detected using the Gene Images CDP-Star detection kit (Amersham Biosciences ${ }^{\circledR}$ ).

\section{Cloning and sequencing of the nit1 gene}

Fragments from the cleavage of phage DNA were cloned into the pZero vector (Invi$\left.\operatorname{trogen}^{\circledR}\right)$. Clones were propagated in One Shot TOP10 E. coli $\left(\right.$ Invitrogen $\left.^{\circledR}\right)$, sequenced, and, when necessary, extracted and purified using the GeneJET ${ }^{\mathrm{TM}}$ Plasmid Miniprep Kit (Life Tools Sciences $\left.^{\circledR}\right)$. The oligonucleotides used in this experiment are listed in Table 1.

Table 1. Description of oligonucleotides used in sequencing and study of nit 1 gene regulation.

\begin{tabular}{rll}
\hline & Oligonucleotides & Sequencing $\left(5^{\prime} \rightarrow 3^{\prime}\right)$ \\
\hline 1 & Niacl1 & GGTTATTATGGGAAACGAGC \\
2 & $\mathrm{Niac12}$ & GCAATTTGGGGTTATCTGG \\
3 & $\mathrm{Niac13}$ & CTATAAGACTGACCTTCCCTC \\
4 & $\mathrm{Niac1}$ & CGCAGAAGCCAAGTTTCT \\
5 & $\mathrm{Niac13b}$ & CCGTTAGTCGTATTAGTCTGG \\
6 & $\mathrm{Niacol} 2$ & GTCAGTGAAGAGGGGTTCAGG \\
7 & $\mathrm{Niacol} 1$ & GGTACTCGGGCATCATCGGC \\
8 & $\mathrm{Clpcr} 1$ & AAGATTTTGGACAGGTCTCAAG \\
9 & $\mathrm{Clpcr} 2$ & CGTCTTGGACAGGTCTCAAG \\
10 & $\mathrm{~T} \mathrm{~F}$ & TAATACGACTCACTATAGGG \\
11 & $\mathrm{M} 13 \mathrm{R}$ & GGATAACAATTTCACACAGG \\
12 & $\mathrm{EF} 1$ & GAAGACTCACATCAAGTCG \\
13 & $\mathrm{EF} 2$ & TTGAAGGAACCCTTGCCGAG \\
\hline
\end{tabular}




\section{C. graminicola and $C$. higginsianum nitl gene characterization and comparison with $C$. lindemuthianum}

For identification of the nit1 gene in the C. graminicola and C. higginsianum database (Colletotrichum Sequencing Project, Broad Institute of Harvard and MIT [http://www. broadinstitute.org/]), we used the $C$. lindemuthianum nit1 gene sequence and BLASTN. The structural characterization was performed by comparison with the $C$. lindemuthianum sequence and manual adjustments. The open reading frame (ORF) was translated using the DNAMan program, and the amino acid sequences were aligned using the ClustalW program.

\section{Phylogenetic analysis of the NIT1 protein}

For phylogenetic analysis, the amino acid sequences of the NIT1 proteins from different groups of fungi were taken from GenBank and aligned using the ClustalW program. Phylogenetic inferences were performed by the neighbor-joining method using the PAUP 4.0b10 program, with bootstrap values using 5000 replicates.

\section{Evaluation of nit1 gene regulation}

The methodology used to study the regulation of this gene was based on studies conducted by Haas et al. (1996) and Pereira et al. (2004). In experiments involving the activation of nit1 gene expression, conidia of fungi were inoculated in potato dextrose (PD) broth. After the growth of mycelium, the samples were transferred to minimal medium (MM) (Pereira et al., 2004) without nitrate, containing $25 \mathrm{mM}$ glutamine as the only source of nitrogen, and grown at $150 \mathrm{rpm}, 24^{\circ} \mathrm{C}$, for $36 \mathrm{~h}$. The mycelium was transferred again to Erlenmeyer flasks containing MM, which was supplemented with $25 \mathrm{mM}$ nitrate as the sole source of nitrogen, and the mycelium was collected at $0,5,15,60$, and $360 \mathrm{~min}$.

In experiments involving the repression of nit 1 gene expression, the reverse order was followed. Mycelia of fungi grown in PD broth were transferred to MM containing $25 \mathrm{mM}$ nitrate as the only source of nitrogen and grown at $150 \mathrm{rpm}, 24^{\circ} \mathrm{C}$, for $36 \mathrm{~h}$. To each Erlenmeyer flask where mycelia were conditioned, a solution of glutamine was added to a final concentration of $25 \mathrm{mM}$, and samples were taken at $0,5,15,60$, and $360 \mathrm{~min}$. In addition to these conditions, fungi grown in PD broth were also transferred to MM containing ammonium or urea as sole nitrogen sources to confirm the repression of the nit 1 gene under these conditions.

Total RNA was extracted using the TRIzol reagent (Invitrogen ${ }^{\circledR}$ ), according to the instructions of the manufacturer. In addition, samples were treated with DNase RQI RNasefree $\left(\right.$ Promega $^{\circledR}$ ). cDNA synthesis was performed using the AMV reverse transcriptase (Promega $^{\circledR}$ ). Polymerase chain reactions (PCRs) were performed to detect cycles corresponding to the logarithmic phase of amplification and to determine how many cycles should be used in subsequent experiments. Primers EF1 and EF2 (which amplify a region of a ribosomal elongation factor of Colletotrichum) were used as endogenous controls in this experiment, while the Clpcr1 and Niacol2 oligonucleotides (Table 1) were used to evaluate gene expression.

\section{Obtaining chlorate-resistant nit1 ${ }^{-}$mutants}

To isolate chlorate-resistant mutants, 4 isolates of C. lindemuthianum (65-400, 
72-801, 73-497, and 81-401) were inoculated in sterile test tubes containing pods set in agar:water and incubated at $22^{\circ} \mathrm{C}$ for 10 days. After growth, a suspension of $10^{7}$ conidia/ $\mathrm{mL}$ in $0.1 \%$ Tween 80 solution was obtained, and $100 \mu \mathrm{L}$ of this suspension was plated on Petri dishes containing minimal basal medium plus $1.5 \% \mathrm{KClO}_{3}$. These plates were incubated at $22^{\circ} \mathrm{C}$ for 20 days. Colonies resistant to chlorate were transferred to culture medium (PD agar), incubated for 7 days at $22^{\circ} \mathrm{C}$, and stored at $4{ }^{\circ} \mathrm{C}$. Phenotypic classes of the obtained mutants were identified by growth on different nitrogen sources: $0.3 \% \mathrm{NaNO}_{3}$, $0.05 \% \mathrm{NaNO}_{2}, 0.02 \%$ hypoxanthine, $0.02 \%$ uric acid, and $0.1 \%$ ammonium tartrate. The results were analyzed using the phenotypic classification for phytopathogenic fungi proposed by Yoder et al. (1986).

\section{Molecular characterization of nit $1^{-}$mutants}

Mycelia of $C$. lindemuthianum were obtained by inoculation of conidia on Petri dishes containing liquid GPYECH medium (Ansari et al., 2004) at $22^{\circ} \mathrm{C}$ for 7 days. Total DNA extraction of mutant and wild-type strains was performed as described by Specht et al. (1982). Aliquots of $5 \mu \mathrm{g}$ total DNA were digested with the restriction enzyme Bam HI, for which there is no site in the nit1 C. lindemuthianum gene. As a probe, the pNIT2.1 plasmid was used, which contains the nit 1 gene fragment from $C$. lindemuthianum. The probe was prepared using the Gene Images ${ }^{\mathrm{TM}}$ Random Prime Labeling Module kit (Amersham Biosciences ${ }^{\circledR}$ ). Labeled DNA fragments were detected using the Gene Images CDP-Star detection kit (Amersham Biosciences $\left.^{\circledR}\right)$.

\section{RESULTS}

\section{Isolation and characterization of the $C$. lindemuthianum nit1 gene}

A total sequence of $3690 \mathrm{bp}$ was obtained from sequencing, corresponding to the $C$. lindemuthianum nit 1 gene. The structural region of this gene was characterized and consisted of $2787 \mathrm{bp}$ (accession No. JF681041). The promoter region was also characterized and consisted of $640 \mathrm{bp}$ as well as $230 \mathrm{bp}$ corresponding to the 3'-flanking region, which contains the polyadenylation signal.

In the promoter region of the C. lindemuthianum nit1 gene (Figure 1), we were able to identify regions that may function as cis-elements for gene expression. There are 3 possible cis-elements: a TATA box located at positions $-105,-271$, and -477 relative to the proposed ATG start codon and $2 \mathrm{GC}$ boxes, located at positions -366 and -452 . The promoter region also contains 4 TATC sequences located at positions $-184,-189,-220$, and -319 . These ciselements are binding sites for the positive regulator AREA of Aspergillus nidulans, NIT2 in Neurospora crassa, and NRE in Penicillium chrysogenum (Caddick et al., 1994; Haas and Marzluf, 1995; Marzluf, 1997). A possible binding region for NIT4 was found, located at position -340 (CTCCGTGT), which differs from the CTCCGHGG consensus described by Punt et al. (1995) only in its last base. In addition, partial palindromic sequences similar to the weak binding site of the NIT4 protein (TCCGTGGC) (Fu and Marzluf, 1993) were found, e.g., CCGCCGGC or CTTCCGTGT. 


\begin{tabular}{|c|c|c|c|c|c|c|}
\hline-640 & TCGTGGAAAG & TATGTTCCAG & ATTATGCCCG & AGTCTCTTTG & TCGTGAGCCT & GCTACCCGCC \\
\hline-580 & GGCTCTATTC & САTСTTCTGC & TCTTTTGATG & GAGGGAACTG & GCTGGCTTAG & TCTACGACTC \\
\hline-520 & TAGTGCCGTG & CGGGTTCTGC & GATGGAGATG & CCGCATGGTA & ATAGTGTGCT & TTCCATCTCA \\
\hline-460 & TCECGCCCCA & TCCCGTCCCA & TCCTGTCCCC & ATGCCGGTCG & 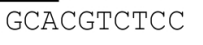 & CTTCCACGTC \\
\hline-400 & СТTTGCCCCC & GTTCGGTGCG & CTTGCGTTCC & GCCCACACCA & CAGACGTGAC & AACTCCGTGT \\
\hline-340 & CTAGGAAGTG & CAGTTTCTAT & C]CACGAGCAG & 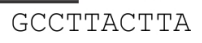 & TTCGATTGTC & ACCCCCAGCG \\
\hline-280 & TTTCGTATAG & GATCCTTCTC & TTTCCTCTGA & АCTCTTCTGT & CAAGCCTTCA & TCCCACTATC \\
\hline-220 & GTTCTGTTCA & & GGTEATAAGC & CTEATdGgt T & ССАСТGATTC & GTCAACGCT C \\
\hline & GTGTTTTGGA & & GTGGG & CACTCACTGC & CAGACAACCT & CTATACGGCA \\
\hline-100 & CAAGCCATCA & ТССААСССАС & $\mathrm{CCAC}$ & GCTTCAGAAC & TAGAACATTT & GGCCTCGCAT \\
\hline & GCAC & & & & & \\
\hline
\end{tabular}

Figure 1. Nucleotide sequence of the nit 1 gene promoter. The possible start codon is in bold, possible cis-elements (TATA box and CG box) are underlined and possible binding sites of general (TATC) and specific (CTCCGTGT)regulatory proteins are surrounded by rectangles.

Analysis of the structural region of the nit 1 gene identified a possible intron. This element starts at position 1808 (relative to the start codon ATG) and ends at position 1877, comprising $69 \mathrm{bp}$. This possible intron presents the 5' GT and 3' AG conserved sequences that are involved in splicing (Ballance, 1986), and an internal consensus sequence, CTGAC, is also present closer to the 3 '-end. The sequence of the nit1 gene of $C$. lindemuthianum was used to search for homology in the $C$. graminicola database to characterize the $C$. graminicola nit1 gene. After screening, the sequence was identified in supercontig 1.8. By comparison and manual adjustments, the ORF of the gene was identified as $2772 \mathrm{bp}$. Similar to $C$. lindemuthianum, the C. graminicola gene contains only one intron, which starts at position 1803 and ends at position 1859, comprising 57 bp. The nitl ORF of C. higginsianum was identified in contig 336 and comprises 2715 bp. Similarly, the $C$. higginsianum nit 1 gene has only one intron, which starts at position 1802 and ends at position 1861, comprising $59 \mathrm{bp}$.

The amino acid sequence of the NIT1 protein was compared to the NIT1 of $C$. higginsianum, C. graminicola (Figure 2), and other fungi (Figure 3). The protein sequence has 905 amino acids with a predicted molecular mass of $101.1 \mathrm{kDa}$. In addition, it has $79 \%$ identity with the NIT1 of $C$. higginsianum and $73 \%$ identity with that of $C$. graminicola. Analysis of the amino acid sequences obtained from C. lindemuthianum, C. higginsianum, and C. graminicola allowed the identification of 3 major regions of NIT1: a binding domain for the molybdenum cofactor, a heme domain, and a binding domain for FAD. In the $C$. lindemuthianum NIT1, the binding domain for the molybdenum cofactor is located near the N-terminus of the protein and starts at $\mathrm{Asp}^{77}$, extending to $\mathrm{Val}^{450}$. In this domain, a cysteine residue was found $\left(\mathrm{Cys}^{174}\right)$ that corresponds to the $A$. nidulans cysteine residue $\left(\mathrm{Cys}^{150}\right)$, which was demonstrated by Garde et al. (1995) as essential for binding of the molybdenum cofactor. The binding domain of heme starts at $\mathrm{Arg}^{516}$ and ends at $\mathrm{Asn}^{593}$. This domain contains the intron as well as a histidine residue $\left(\mathrm{His}^{579}\right.$ ) corresponding to the histidine residue of $A$. nidulans $\left(\mathrm{His}^{547}\right.$ ), which was demonstrated by Garde et al. (1995) as essential for NIT1 functioning. Within the FAD domain, which extends from $\mathrm{Glu}^{638}$ to the end of the protein sequence, there are 2 amino acids important for its function, $\operatorname{Trp}^{651}$ and $\mathrm{His}^{687}$. It was previously shown that replacing $\operatorname{Trp}^{618}$ of the $A$. nidulans NIT1 protein, which corresponds to $\operatorname{Tr}^{651}$ of $C$. lindemuthianum, with lysine resulted in transformants that were able to grow at $30^{\circ} \mathrm{C}$ but not at $37^{\circ} \mathrm{C}$, when their sole source of nitrogen was nitrate. The $\mathrm{His}^{654}$ of the $A$. nidulans NIAD protein, which corresponds 
to $\mathrm{His}^{687}$ of $C$. lindemuthianum, is not essential but has been demonstrated to be important for protein function (Garde et al., 1995). Using the amino acid sequences of these NIT1 proteins, a phylogenetic analysis was performed by aligning the NIT1 enzyme sequences of several fungi and plants. Figure 3 shows the consensus phylogenetic tree that was obtained, plus the bootstrap values utilizing 5000 replications.

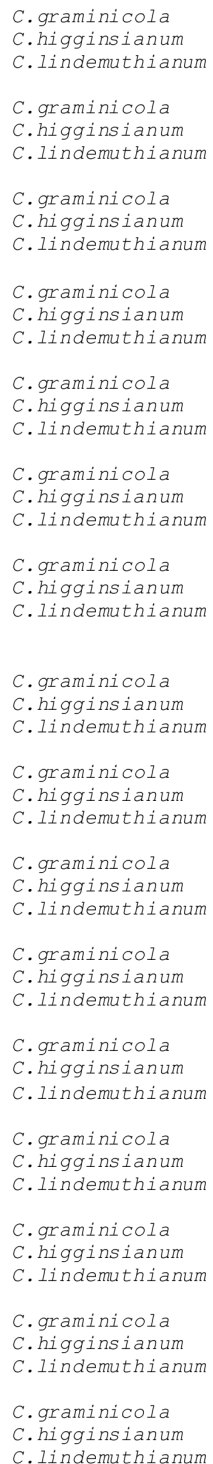

Figure 2. Aligned amino acid sequences of the Colletotrichum lindemuthianum, C. graminicola and C. higginsianum NIT1 proteins. The three main domains of nitrate reductase are highlighted in the figure: the binding domain of the molybdenum cofactor is shaded in gray, the heme domain is underlined, and the binding domain of FAD is highlighted in black. 


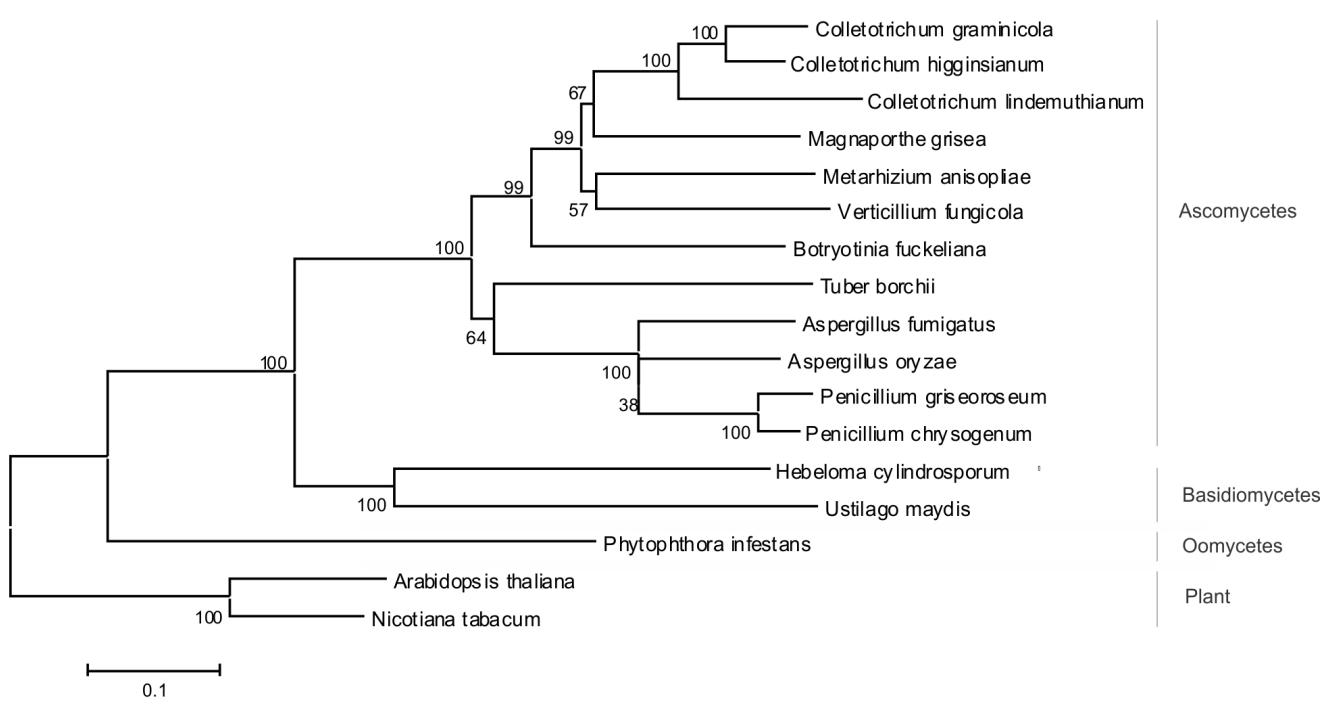

Figure 3. Phylogenetic analysis of the nitrate reductase protein. The rooted tree was based on a comparison of the Colletotrichum lindemuthianum nitrate reductase amino acid sequence with that of other filamentous fungi. The values of the bootstrap percentage are shown in each branch and based on 5000 replicates. GenBank accession Nos.: Nicotiana tabacum (CAA32217.1); Arabdopsis thaliana (NP_177899.1); Phytophtora infestans (AAA86681); Ustilago maydis (71019527); Hebeloma cylindrosporum (CAB60010.1); Penicillium chrysogenum (AAB03900.1); Penicillium griseoroseum (AAP12556.1); Aspergillus fumigatus (AAL85636.1); Aspergillus oryzae (BAA08551.1); Tuber borchii (AAN64993.1); Botryotinia fuckeliana (AAC02633.1); Verticillium fungicola (AAO63560.1); Metarhizium anisopliae (CAA04554.1); Magnaporthe grisea (XP 369402.1); C. lindemuthianum (JF681041); C. graminicola and C. higginsianum (Colletotrichum Sequencing Project, Broad Institute of Harvard and MIT (http://www.broadinstitute.org/)).

The tree branches were well sustained with, in most clades, bootstrap values above $99 \%$, indicating a consistent and robust phylogenetic tree. A high degree of tree consistency indicates that the analyzed genes coding for NIT1 probably had a common origin and can, therefore, be considered counterparts of each other. A clear division between different groups directly correlated with the taxonomic category to which they belong could be noticed, reflecting their possible evolutionary history.

In addition, a correlation was found between the characteristics of each individual and group division observed in the tree. Zhou and Kleinhofs (1996) reported that the number of introns was an important correlation in the group ascomycetes. Interestingly, all individuals in the branch containing Aspergillus fumigatus have 6 introns in conserved regions and belong to the same taxonomic order. Similarly, the branch containing Botryotinia fuckeliana is characterized by fungi whose nit 1 genes contain none or only one intron. Although Hebeloma cylindrosporum and Ustilago maydis differ regarding the number of introns, with 12 and none, respectively, the identity of the NIT1 protein sequence was high enough for them to be grouped in the same class, reflecting that they belong to the same taxon. C. lindemuthianum, C. graminicola, and C. higginsianum have high identity in their NIT1 protein sequence and cluster close in the tree, as expected. 


\section{Study of $C$. lindemuthianum nit1 gene regulation}

To verify the regulation of nitrate assimilation by $C$. lindemuthianum, induction and repression experiments of the nit 1 gene were performed, and semi-quantitative reverse transcription-PCR (RT-PCR) using 23 amplification cycles was used to evaluate the presence of nit 1 gene transcripts under different cultivation conditions. The results of the sequence analysis of the promoter region of this experiment indicated that the nitl gene could be regulated in a positive way, as cis-elements specific for positive regulators were found.

The results showed that $C$. lindemuthianum nit 1 gene transcription is activated by $\mathrm{NaNO}_{3}$ and repressed by glutamine, ammonium, and urea (Figure 4). Repression experiments were performed by growing mycelia in MM containing nitrate as the sole source of nitrogen and adding glutamine at $0,5,15,60$, and $360 \mathrm{~min}$ (Haas et al., 1996). Under these conditions, no difference was found in the cDNA of nit 1 at 0 and 5 min. Reduced nit 1 cDNA was found at 15 min after glutamine addition, and nit 1 cDNA was undetectable at 60 and 360 min after glutamine addition (Figure 4A).

Activation experiments were performed by growing mycelia in the presence of glutamine for $36 \mathrm{~h}$ and transferring to MM containing nitrate as the nitrogen source at $0,5,15$, 60 , and 360 min (Haas et al., 1996). At time zero, no nit 1 cDNA was detected. nit 1 cDNA was first observed at $15 \mathrm{~min}$ after transfer to $\mathrm{MM}$, and at $60 \mathrm{~min}$ after transfer, nit 1 gene transcripts were observed at near maximal levels. Maximal levels of gene transcription were obtained after $360 \mathrm{~min}$ in MM (Figure 4B).

A

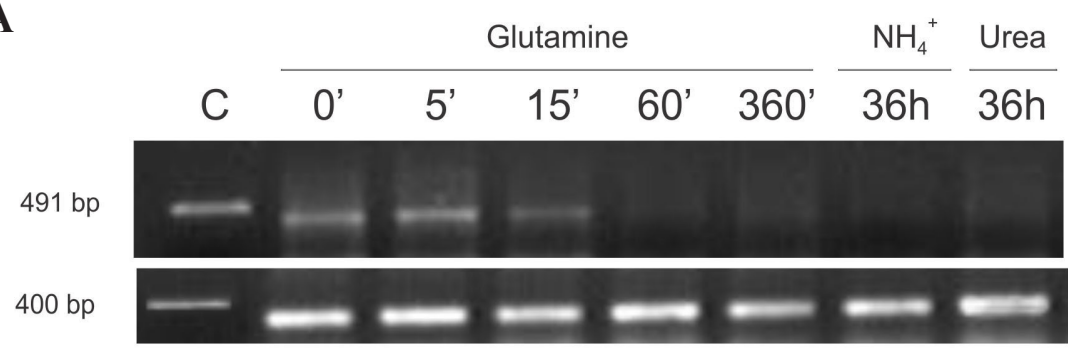

B

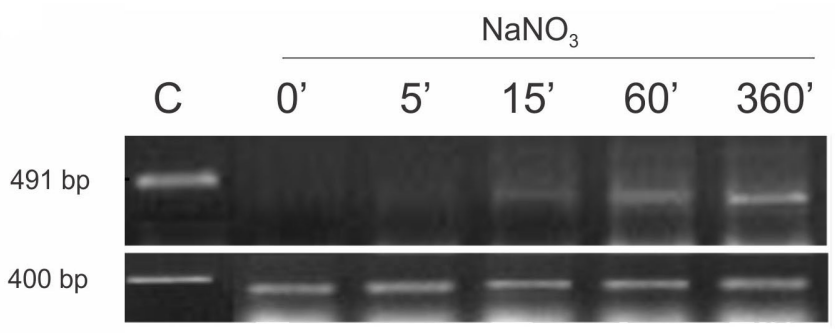

Figure 4. Analysis of Colletotrichum lindemuthianum nitl gene transcription by RT-PCR. A. Analysis of gene repression from mycelia cultivated in media containing nitrate as the nitrogen source and collected after the addition of glutamine at the times indicated. Suppression was also examined in mycelia cultivated in $\mathrm{NH}_{4}^{+}$and urea. $\mathbf{B}$. Analysis of gene activation in mycelia cultivated on glutamine and collected after transfer to medium containing nitrate as the nitrogen source at the times indicated. Internal positive controls for detection of cDNA in each real-time reaction were the amplification of cDNA with EF1 and EF2 oligonucleotides, which amplify a region of approximately $400 \mathrm{bp}$ of a constitutively expressed gene that codes for the ribosomal elongation factor. Lane $C$ = positive control. 


\section{Isolation and characterization of nit $1^{-}$mutants}

Selection in medium containing chlorate allowed the isolation of 102 mutants (Table 2), which were then classified phenotypically by growth in media containing different nitrogen sources. Four physiological races of $C$. lindemuthianum produced spontaneous mutants, although at very different frequencies. Race 72-801 had the largest number of nit1- mutants.

Table 2. Selection of chlorate-resistant mutants.
\begin{tabular}{lcccc}
\hline \multicolumn{5}{l}{ Physiological races } \\
\cline { 2 - 5 } Mutants & $65-400$ & $72-801$ & $73-497$ & $81-401$ \\
\hline Total & 9 & 59 & 21 & 13 \\
nit $I^{-}$ & 2 & 20 & 3 & - \\
\hline
\end{tabular}

Values for nit $^{-}$mutants were obtained after phenotypically classification.

For molecular characterization, we selected 10 mutants (race 72-801). Total DNA was extracted, digested with the BamHI enzyme, and hybridized with the $C$. lindemuthianum nit 1 gene (Figure 5).

Although the vast majority of mutants showed hybridization profiles similar to the wild-type strain, possibly indicating the occurrence of point mutations in the nit 1 gene, some mutants had interesting profiles. Mutants 17A, 21A, and 26A presented a band significantly smaller than the wild-type strain, indicating a deletion event. Mutant 32A presented a band with a fragment size greater than that of the wild-type strain, indicating the insertion of a transposable element in the nit1 gene.
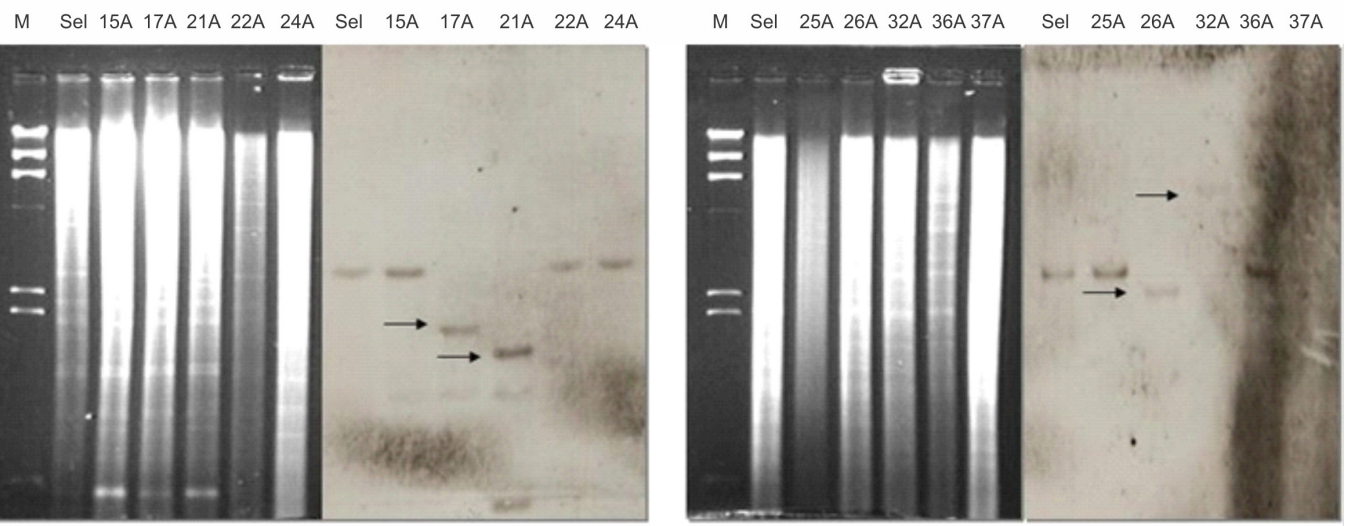

Figure 5. Analysis of different nit $1^{-}$mutants. Lane $M=$ DNA of $\lambda$ bacteriophage digested with enzyme HindIII; lane $\mathrm{Sel}=$ a wild strain (physiologic race 72-801); other numbers represent different $n i t 1^{-}$mutants phenotypically classified in media containing different nitrogen sources. As probe, we used a gene fragment of Colletotrichum lindemuthianum nitl. 


\section{DISCUSSION}

Screening of the $C$. lindemuthianum genomic library enabled the isolation and characterization of a nucleotide sequence of $3690 \mathrm{bp}$ corresponding to the nit1 gene, which encodes the enzyme NIT1.

In the promoter region of the C. lindemuthianum nit1 gene (Figure 1), in addition to TATA box and GC box cis-elements, 4 TATC sequences were identified, located at positions $-184,-189,-220$, and -319 . These cis-elements are binding sites of the general positive regulators AREA of $A$. nidulans, NIT2 of $N$. crassa, and NRE of $P$. chrysogenum (Caddick et al., 1994; Haas and Marzluf, 1995; Marzluf, 1997). Elements with at least 2 copies of GATA sequences, separated by approximately $30 \mathrm{bp}$ and either oriented in the same or opposite directions, are considered strong binding sites for NIT2 (Haas and Marzluf, 1995). In P. chrysogenum, strong binding sites of NRE were described by Haas and Marzluf (1995) as regions with at least 2 GATA sequences separated by 5 and $27 \mathrm{bp}$, configured either in the same direction or in opposite directions. GATA elements separated by 74 or $96 \mathrm{bp}$ did not provide strong binding sites for NRE (Haas and Marzluf, 1995). In C. lindemuthianum, 2 TATC regions, located at positions -184 and -220 , are separated by 32 nucleotides and, therefore, may constitute a strong binding region of a regulatory general nitrogen assimilation protein. Another possible binding site for this protein would be between the cis-elements located at positions -189 and -220 , which are separated by 23 nucleotides. Strong binding of the P. chrysogenum NRE to 2 GATA factors may be related to functioning of the protein in a dimeric form, which has also been suggested for NIT2 in N. crassa (Feng et al., 1993; Haas and Marzluf, 1995).

The analysis of the structural region of the C. lindemuthianum nit 1 gene enabled full characterization of a sequence of $2787 \mathrm{bp}$, which is interrupted by a single intron. Similarly, the analysis of the structural region of the $C$. higginsianum and C. graminicola nit1 genes enabled the identification of sequences of 2772 and $2715 \mathrm{bp}$, respectively, both interrupted by a single intron.

In filamentous fungi, sequence analysis of genes encoding NIT1 reveals variations in the presence and size of introns. The positions of introns tend to be conserved within kingdoms but differ between the fungi and plant kingdoms (Zhou and Kleinhofs, 1996). For the fungi U. maydis (Banks et al., 1993) and B. fuckeliana (Levis et al., 1997a), there is no report of introns in their nit1 genes, while the nit1 gene of the fungus $H$. cylindrosporum (Jargeat et al., 2000) contains 12 introns. In P. camemberti, 6 introns were located in conserved regions, although they were of different size (Navarrete et al., 2009). The nit1 genes of Beauveria bassiana, Fusarium oxysporum, Gibberella fujikuroi, Metarhizium anisopliae, and Verticillium fungicola also contain a single intron, and its location is restricted to the heme domain of the protein, which appears to be an ancestral feature of the protein for these organisms. In general, in fungi, most introns within the nitl genes are located in conserved regions that correspond to the binding domain for the molybdenum cofactor. In plants such as Lycopersicon esculentum, Nicotiana tabacum, Oryza sativa, and P. vulgaris, the 3 introns present in these species occupy the same position. In general, these introns tend to occupy regions within and not between functional domains (Zhou and Kleinhofs, 1996).

Translation of the sequence of the characterized structural region allowed for the calculation of a protein comprising 905 amino acids with a molecular weight of $101.1 \mathrm{kDa}$, which corresponds to the $C$. lindemuthianum NIT1 protein (Figure 2). This is also the approximate 
size of proteins calculated for C. higginsianum and C. graminicola, which comprise 904 amino acids and have a molecular weight of approximately $100.7 \mathrm{kDa}$. The amino acid sequence of the $C$. lindemuthianum NIT1 protein showed high identity with those of other fungi, which indicates that this protein is evolutionarily conserved. In addition, it has been reported that because of the conservation of NIT1 protein domains, high identity can be observed between the proteins of fungi and plants and functionally related proteins of mammals, e.g., sulfite oxidase, cytochrome b5, and NADH-cytochrome b5 reductase (Campbell and Kinghorn, 1990).

Filamentous fungi generally have strong regulatory mechanisms for the assimilation of nitrate by means of positive and negative regulators that ensure metabolic repression when primary sources of nitrogen such as ammonium or glutamine are present. We also performed a study of the induction and repression of the $C$. lindemuthianum nit 1 gene by cultivating the fungus on different nitrogen sources. As shown in Figure 4, transcripts of the nit 1 gene could not be detected when the fungus was cultured in media containing ammonium or urea as the sole nitrogen source. We also observed that after 15 min of growth in media containing glutamine, the transcription level decreased to approximately half.

Similar results were obtained by Haas et al. (1996) and Pereira et al. (2004) when studying the nitl gene regulation of the fungi $P$. chrysogenum and P. griseoroseum. In $N$. crassa, the estimated half-life of NIT3 mRNA was only 5 min (Okamoto et al., 1991). This sharp decrease in the NIT1 mRNA level is a mechanism that allows the cell to respond quickly to the nutritional condition of the environment and ensures great economy in terms of energy because assimilation of a more metabolically available nitrogen source can occur. In $N$. crassa, the enzymatic activity of NIT3 decreases relatively quickly in mycelia growing in primary nitrogen sources, with a half-life of about 15 min (Okamoto et al., 1991). According to these authors, this relatively rapid decline of the enzymatic activity helps to ensure the preferential use of primary sources of nitrogen.

Finally, it took 15 min until nitl gene transcripts could be detected during induction of the gene with $\mathrm{NaNO}_{3}$. A quick response to this condition is also reported for $N$. crassa (Okamoto et al., 1991), P. chrysogenum (Haas et al., 1996), and P. griseoroseum (Pereira et al., 2004). In N. crassa, the NIT3 mRNA rises to maximal levels after just $15 \mathrm{~min}$ of induction by nitrate, and the activity of the NIT3 protein increases rapidly in the first 15-20 min, reaching a peak at 60 min (Okamoto et al., 1991).

In addition to its participation in metabolic pathways of nitrogen assimilation, the gene that encodes NIT1 has been highlighted in recent studies for the use in the detection and isolation of transposable elements. It has been suggested that stress conditions, e.g., the presence of chlorate, can trigger the movement of transposable elements, resulting in a high frequency of spontaneous mutations. Transposition in response to environmental stress has been proposed as an adaptive response of the genome and has been detected in various organisms, including fungi, yeasts, and plants (McClintock, 1984; Capy et al., 2000). In this study, we successfully used a system for positive selection of spontaneous mutations in the nit 1 gene, allowing the isolation of 20 nit $1^{-}$mutants. Ten of them were analyzed by DNA hybridization to assess the nature of the mutations. The different profiles of hybridization (Figure 5) suggest the presence of transposable elements in C. lindemuthianum. In fact, this system has been used very successfully for the isolation of several transposable elements in fungi. The fot 1, impala, Ant1, Vader, Flipper, and bupfer elements are examples of transposons cloned by selection of spontaneous mutations in the gene that encodes NIT1 in F. oxysporum, Aspergillus niger, A. 
fumigatus, Botrytis cinerea, and B. bassiana, respectively (Daboussi et al., 1992; Langin et al., 1995; Glayzer et al., 1995; Amutan et al., 1996; Levis et al., 1997b; Maurer et al., 1997). However, for a better understanding of the genetic mechanisms responsible for the different profiles obtained by hybridization of the mutant $C$. lindemuthianum nit1, our future studies will focus on determining the nature of this source of variation among strains, investigating to what extent this variation can be explained by the presence of active transposable elements.

\section{ACKNOWLEDGMENTS}

Research supported by Fundação de Amparo à Pesquisa do Estado de Minas Gerais (FAPEMIG) and Conselho Nacional de Desenvolvimento Científico e Tecnológico (CNPq).

\section{REFERENCES}

Amutan M, Nyyssonen E, Stubbs J, Diaz-Torres MR, et al. (1996). Identification and cloning of a mobile transposon from Aspergillus niger var. awamori. Curr. Genet. 29: 468-473.

Ansari KI, Palacios N, Araya C, Langin T, et al. (2004). Pathogenic and genetic variability among Colletotrichum lindemuthianum isolates of different geographic origins. Plant. Pathol. 53: 635-642.

Ballance DJ (1986). Sequences important for gene expression in filamentous fungi. Yeast 2: 229-236.

Banks GR, Shelton PA, Kanuga N, Holden DW, et al. (1993). The Ustilago maydis narl gene encoding nitrate reductase activity: sequence and transcriptional regulation. Gene 131: 69-78.

Benton WD and Davis RW (1977). Screening lambdagt recombinant clones by hybridization to single plaques in situ. Science 196: 180-182.

Caddick MX, Peters D and Platt A (1994). Nitrogen regulation in fungi. Antonie Van Leeuwenhoek 65: 169-177.

Campbell WH and Kinghorn KR (1990). Functional domains of assimilatory nitrate reductases and nitrite reductases. Trends Biochem. Sci. 15: 315-319.

Capy P, Gasperi G, Biemont C and Bazin C (2000). Stress and transposable elements: co-evolution or useful parasites? Heredity 85: 101-106.

Casela CR and Frederiksen RA (1994). Pathogenic variation in monoconidial culture from a single lesion and monoconodial subcultures of the sorghum anthracnose fungus Colletotrichum graminicola. Trop. Plant Pathol. 19: 149-153.

Castro-Prado MA, Querol CB, Sant'Anna JR, Miyamoto CT, et al. (2007). Vegetative compatibility and parasexual segregation in Colletotrichum lindemuthianum, a fungal pathogen of the common bean. Genet. Mol. Res. 6: 634-642.

Colletotrichum Sequencing Project, Broad Institute of Harvard and MIT (2011). Available at [http://www.broadinstitute. org/]. Accessed July, 2011.

Daboussi MJ and Capy P (2003). Transposable elements in filamentous fungi. Annu. Rev. Microbiol. 57: 275-299.

Daboussi MJ, Langin T and Brygoo Y (1992). Fot1, a new family of fungal transposable elements. Mol. Gen. Genet. 232: 12-16.

Fávaro LCL, Araújo WL, Souza-Paccola EA, Azevedo JL, et al. (2007). Colletotrichum sublineolum genetic instability assessed by mutants resistents to chlorate. Mycol. Res. 111: 93-105.

Feng B, Xiao X and Marzluf GA (1993). Recognition of specific nucleotide bases and cooperative DNA binding by the trans-acting nitrogen regulatory protein NIT2 of Neurospora crassa. Nucleic Acid Res. 21: 3989-3996.

Fu YH and Marzluf GA (1993). Nuclear DNA-binding which recognize nitrate reductase in Neurospora crassa. $J$. Bacteriol. 175: 2379-2392.

Galagan JE, Henn MR, Ma LJ, Cuomo CA, et al. (2005). Genomics of the fungal kingdom: insights into eukaryotic biology. Genome Res. 15: 1620-1631.

Garde J, Kinghorn JR and Tomsett AB (1995). Site-directed mutagenesis of nitrate reductase from Aspergillus nidulans. Identification of some essential and some nonessential amino acids among conserved residues. J. Biol. Chem. 270: 6644-6650.

Glayzer DC, Roberts IN, Archer DB and Oliver RP (1995). The isolation of Ant1, a transposable element from Aspergillus niger. Mol. Gen. Genet. 249: 432-438.

Haas H and Marzluf GA (1995). NRE, the major nitrogen regulatory protein of Penicillium chrysogenum, binds specifically to elements in the intergenic promoter regions of nitrate assimilation and penicillin biosynthetic gene clusters. Curr. 
Genet. 28: 177-183.

Haas H, Marx F, Graessle S and Stoffler G (1996). Sequence analysis and expression of the Penicillium chrysogenum nitrate reductase encoding gene (niaD). Biochim. Biophys. Acta 1309: 81-84.

Ishikawa FH, Souza EA, Read ND and Roca MG (2010). Live-cell imaging of conidial fusion in the bean pathogen, Colletotrichum lindemuthianum. Fungal Biol. 114: 2-9.

Jargeat P, Gay G, Debaud JC and Marmeisse R (2000). Transcription of a nitrate reductase gene isolated from the symbiotic basidiomycete fungus Hebeloma cylindrosporum does not require induction by nitrate. Mol. Gen. Genet. 263: 948-956.

Langin T, Capy P and Daboussi MJ (1995). The transposable element impala, a fungal member of the Tc1-mariner superfamily. Mol. Gen. Genet. 246: 19-28.

Levis C, Fortini D and Brygoo Y (1997a). Transformation of Botrytis cinerea with the nitrate reductase gene (niaD) shows a high frequency of homologous recombination. Curr. Genet. 32: 157-162.

Levis C, Fortini D and Brygoo Y (1997b). Flipper, a mobile Fot1-like transposable element in Botrytis cinerea. Mol. Gen. Genet. 254: 674-680.

Marzluf GA (1997). Genetic regulation of nitrogen metabolism in the fungi. Microbiol. Mol. Biol. Rev. 61: 17-32.

Maurer P, Rejasse A, Capy P, Langin T, et al. (1997). Isolation of the transposable element hupfer from the entomopathogenic fungus Beauveria bassiana by insertion mutagenesis of the nitrate reductase structural gene. Mol. Gen. Genet. 256: 195-202.

McClintock B (1984). The significance of responses of the genome to challenge. Science 226: 792-801.

Navarrete K, Roa A, Vaca I, Espinosa Y, et al. (2009). Molecular characterization of the niaD and pyrG genes from Penicillium camemberti, and their use as transformation markers. Cell Mol. Biol. Lett. 14: 692-702.

Okamoto PM, Fu YH and Marzluf GA (1991). Nit-3, the structural gene of nitrate reductase in Neurospora crassa: nucleotide sequence and regulation of mRNA synthesis and turnover. Mol. Gen. Genet. 227: 213-223.

Oliveira VC and Costa JLS (2003). Compatibilidade vegetativa de nit-mutantes de Fusarium solani patogênicos e nãopatogênicos ao feijoeiro e à soja. Fitopatol. Bras. 28: 89-92.

Pereira JF, de Queiroz MV, Lopes FJ, Rocha RB, et al. (2004). Characterization, regulation, and phylogenetic analyses of the Penicillium griseoroseum nitrate reductase gene and its use as selection marker for homologous transformation. Can. J. Microbiol. 50: 891-900.

Perfect SE, Hughes HB, O’Connell RJ and Green JR (1999). Colletotrichum: A model genus for studies on pathology and fungal-plant interactions. Fungal Genet. Biol. 27: 186-198.

Punt PJ, Strauss J, Smit R, Kinghorn JR, et al. (1995). The intergenic region between the divergently transcribed niiA and niaD genes of Aspergillus nidulans contains multiple NirA binding sites which act bidirectionally. Mol. Cell Biol. 15: 5688-5699.

Rodríguez-Guerra R, Ramírez-Rueda MT, De La Veja OM and Simpson J (2003). Variation in genotype, pathotype and anastomosis groups of Colletotrichum lindemuthianum isolates from México. Plant Pathol. 52: 228-235.

Soares MA (2007). Genes Determinantes de Patogenicidade e Virulência e Análise Parcial do Genoma Mitocondrial de Colletotrichum lindemuthianum, Agente Causal da Antracnose do Feijoeiro Comum. Doctoral thesis, Universidade Federal de Viçosa, Viçosa.

Specht CA, DiRusso CC, Novotny CP and Ullrich RC (1982). A method for extracting high-molecular-weight deoxyribonucleic acid from fungi. Anal. Biochem. 119: 158-163.

Yoder OC, Valent B and Chumley F (1986). Genetic nomenclature and practice for plant pathogenic fungi. Phytopatology 76: 383-385.

Zhou J and Kleinhofs A (1996). Molecular evolution of nitrate reductase genes. J. Mol. Evol. 42: 432-442. 